\title{
EGYETEMI TESTNEVELÉS ÉS SPORT HATÁSA A HALLGATÓK FITTSÉGI ÁLLAPOTÁRA
}

\author{
THE EFFECT OF PHYSICAL EDUCATION AND SPORT ON FITNESS STATUS of \\ UNIVERSITY STUDENTS
}

\author{
József Márton Pucsok, László Balogh, Katalin Varga, Eszter Bíró, Gabriella Perényi,, Andrea \\ Puskás Lenténé
}

Debreceni Egyetem, Sporttudományi Koordinációs Intézet, Debrecen

\section{Összefoglaló}

A felsőoktatási intézményekben tanuló diákok, fiatal felnőttek fizikai fittsége romló tendenciát mutat. E folyamat okainak megvizsgálásához releváns adatokra van szükség. Ennek érdekében a 2017-18-as tanévtól kezdve, egy longitudinális felmérés-sorozat keretében az egyetemi testnevelés órák és sportfoglalkozások hatását vizsgáltuk meg. Első ütemben hatvan inaktív hallgató, férfiak és nők egyaránt (a Debreceni Egyetem tanulói) fittségi állapotát mértük fel a mozgásprogram elkezdése elôtt, majd utána. A vizsgálatban résztvevoók heti egy alkalommal 90 perces sportfoglalkozásokon (pilates, spinning, wellness-általános kondicionálás, alakformálás) vettek részt. A szemeszter elején és végén a résztvevők a Hungarofit tesztrendszerből ismert három motoros próbát (ingafutás (Beep teszt), karhajlitás-nyújtás, felülés) hajtottak végre.

Eredményeink azt mutatták, hogy a négy sporttevékenység az aerob teljesítőképességre, a felső végtag és a hasizom-törzs erő-állóképességére is eltérő módon hatott. Bár a nemzetközi ajánlások heti 150 perc fizikai aktivitást javasolnak, heti egyszeri másfél órás közepes intenzítású mozgással is fejleszthetö. a motoros képességek szintje.

Kulcsszavak: fizikai aktivitás, fizikai teljesítőképesség, fiatal felnőttek

\begin{abstract}
The physical fitness state of university students has deteriorated over the years. Relevant data is needed to investigate this tendency thoroughly. We conducted a longitudinal examination among university students in Debrecen, Hungary. At the first stage of our examinations, we examined sixty male and female participants to assess their physical fitness status. They participated in four different activities (pilates, spinning, wellness-general fitness, body-shaping) once a week. Each exercise session lasted for 90 minutes. We conducted a pre-and post-exercise screening, which consisted of a Beep-test, push-up, and sit-up tests.

We hypothesized that the different types of activities might alter the exercise response. Aerobic performance, upper-body, and abdominal strength may differ depending on the type of exerciseinternational recommendations suggesting that 150 minutes of physical activity is necessary for physical fitness benefits. Our results demonstrated that 90 minutes of exercise might significantly improve inactive young adults' physical fitness state once a week.
\end{abstract}


Vol 3, No 2 (2020): Stadium-Hungarian Journal of Sport Sciences

https://doi.org/10.36439/SHJS/2020/2/8599

Keywords: physical activity, general physical fitness, young adults

\section{ELMÉLETI HÁTTÉR}

A fiatal felnőttek fizikai teljesítőképessége évek óta egyre romló tendenciát mutat. A felsőoktatásban résztvevő hallgatók zöme, a középiskola elvégzése után felhagy a rendszeres sporttevékenységgel (Kaj, 2015; Kaj, 2017). A rendszerváltás éveit követően az egyetemisták szinte minden fittségi mutató (aerob teljesítmény, erő-állóképesség, egyensúlyozó-képesség, ízületi mozgékonyság) tekintetében rosszabb eredményeket produkálnak (Barabás et al., 1992; Bucsy-Katona, 2002). A hazánkban megfigyelhető tendenciák követik a nemzetközi trendeket. Európában (Telama-Yang, 2000; Steptoe et al., 2002; WHO, 2018), Amerikában (Caspersen et al., 2000; Pribis et al., 2010) is csökken a fiatalok által rendszeresen végzett fizikai aktivitás mennyísége, ezzel párhuzamosan az általános edzettségi szintjük is gyengébb. Különösen a tengerentúlon romlott az aerob állóképesség szintje, ami magasabb BMI értékeket eredményezett (Pribis et al., 2010). Hazánkban eddig két nagy elemszámú reprezentatív kutatás mérte felsőoktatásban résztvevő hallgatók fizikai állapotát. Az első a 90-es években, a MEFS által koordinált felmérés-sorozat, 8100 fő adatait dolgozta fel, ez az eddigi legnagyobb elemszámú ilyen jellegű kutatás Magyarországon. Az ország összes felsőoktatási intézményét érintő vizsgálat megállapította, hogy a vizsgálatban résztvevők túlnyomó részénél a heti egyszeri kötelező testnevelés jelenti a rendszeres fizikai aktivitás egyetlen formáját. A diplomás fiatalok egészségi és fittségi állapota, a Nyugat-európai társaikéhoz hasonló (Frenkl, 1997). A fizikai aktivitás gyakoriságát és mennyíségét tekintve ezek a negatív trendek a kétezres években még felerősödtek (Hamar et al., 2006; Kovács et al., 2002). Az inaktivitáshoz egészségtelen életviteli szokások, fokozott alkoholfogyasztás, dohányzás és rendszertelen táplálkozás társul (Antal et al., 2003; Konczos et al., 2012).

A második kutatás több mint tíz évvel később, közel ötszáz, százhuszon-három férfi és háromszáz-kilenc nő egyetemista antropometriai és fittségi adatait tartalmazta. A több szemeszteren át tartó longitudinális felmérés-sorozat így reális képet adott a résztvevők fittségi állapotának változásáról. Kay és munkatársainak felmérése a testtömeg-index, testzsír-százalék, börredő vastagság regisztrálása mellett az Eurofit tesztrendszer kilenc motoros próbáját alkalmazta (Kay et al., 2015). A 2011-12-es felmérés alapján megállapítható hogy az egyensúly, gyorsaság, hajlékonyság, hasizom erő-állóképessége, aerob állóképesség tekintetében, romlottak az eredmények, míg a szorítóerő és hajlított karú függés próbákban nyújtott teljesítmény javult az 1997-98-as adatokhoz képest.

A rendszeres testmozgás számos szív-érrendszeri, mozgásszervi és anyagcsere betegség megelőzésének egyik leghatékonyabb eszköze. Az elhízással járó többlet-testsúly számos krónikus betegség közvetlen kiváltó oka lehet, a testsúlyszabályzás leghatásosabb módja a rendszeres sportolás (Perényi-Pertidis, 2015). A fizikailag aktív életmód, az egészségi 
állapot, a mortalitás között pozitív korrelációs kapcsolat áll fenn (Flegal et al., 2013; Moore et al., 2012, Warburton et al., 2006). Moore és munkatársai nagy elemszámon elvégzett, több mint 600 ezer fős vizsgálata pozitív kapcsolatot talált a fizikai aktivitás, az alacsonyabb testtömeg-index (BMI) és a várható élettartam között. Az aktív életmódot élő, alacsonyabb BMI-vel rendelkező egyének 1,8-7,2 évvel élnek tovább inaktív kortársaiknál. Wen és munkatársai több mint 400 ezer fő bevonásával végzett követéses vizsgálata hasonló eredményeket hozott. A kutatók rendszeresen sportoló nők esetében átlagosan 3,67, férfiaknál 4,21 év élettartam növekedést regisztráltak (Wen et al., 2011). Hungarostudy néven a magyar lakosság körében végzett vizsgálatok eredményei is a testmozgás jótékony hatásait bizonyítják. Egy inaktív férfi háromszor nagyobb valószínűséggel hal meg idő előtt, mint az, aki rendszeres testmozgást végez. Nők esetében ez az összefüggés még erőteljesebben mutatkozik, itt négyszeres különbség mutatható ki. (Kopp-Skrabski 2009). A fiatalok körében is egyre inkább jellemző inaktív életmód, komoly népegészségügyi kockázatot jelent (Ács et al., 2011; Bartha-Perényi, 2015).

A rendszeres fizikai aktivitás intenzitása és gyakorisága tekintetében eltérő eredményeket kapunk ha megvizsgáljuk a nemzetközi ajánlásokat. Az American College of Sports Medicine ajánlása alapján (Garber et al. 2011) közepes (60-70 százalékos) intenzitás mellett, heti legalább 150 perc testmozgást ajánlanak a kutatók. Napi fél óra is elegendő lehet, egyszerre vagy 10 perces blokkokban végezve. A másik ajánlás szerint 20 perces intenzívebb tempójú sporttevékenység heti legalább háromszor végezve szintén pozitív egészségvédő hatást vált ki.

\section{ALAPFELTEVÉSEK}

1. Feltételezzük, hogy a felmérésben résztvevő fiatal, inaktív felnőttek, a Debreceni Egyetem hallgatói már heti egyszeri, 90 perces egy féléven keresztül rendszeresen végzett sporttevékenység hatására bizonyos motoros próbákban nyújtott teljesítményükben javulni fognak.

2. Feltételezzük, hogy a négy különféle sporttevékenység (alakformálás, spinning, wellness-általános kondicionálás, pilates) más-más mértékben javítja a hasizom, a felső végtag erő-állóképességét, és az aerob állóképességet. Azaz mind a négy mozgásforma az általános egészségi állapot szempontjából jótékony hatással bír, bizonyos motoros képességek javulása tekintetében azonban lesznek különbségek.

\section{MÓDSZER}

\section{A VIZSGÁLATOK CÉLKITÛZÉSE}

Vizsgálatunkhoz olyan rekreációs hatással bíró mozgásprogramokat választottunk pilates, spinning, wellness-általános kondicionálás és alakformálás -, amelyek alkalmasak voltak arra, hogy egyetemi hallgatóknál a fizikai aktivitás stressz tưrésre gyakorolt és a feltöltődés érdekében kifejtett pozitív hatását mérjük fel. Az egészségmegőrző 
mozgásprogramok megvalósításával az általános jó közérzet, a teljes testi és lelki kiegyensúlyozottság elérésének lehetőségeit tanulmányoztuk.

\section{VIZSGÁLATI SZEMÉLYEK}

A vizsgálatsorozatba fiatal inaktív felnőtteket, férfiakat és nőket egyaránt, a Debreceni Egyetem hallgatóit vontuk be. A résztvevők négy csoportban, heti egyszeri 90 perces egyetemi testnevelésórán vettek részt. Huszonheten a pilates, tíz fő az alakformálás, öt fő a spinning, tizennyolc fő a wellness-általános kondicionálás csoportba jelentkezett. A mozgásprogramok és az ahhoz kapcsolódó felmérések a 2017/18-as tanév második szemeszterétől indultak. Négy féléven keresztül egy longitudinális vizsgálat keretében mértük fel a hallgatók csoportjait. A célcsoportoknál az egyetemi testnevelés órákon fittségi méréseket végeztünk. A vizsgálatban résztvevők a kondicionális képességeket mérő próbák közül a 20 méteres ingafutást (Beep tesztet), a mellső fekvőtámaszban karhajlítás és nyújtás próbát, valamint a felülés tesztet hajtották végre. A résztvevők a fittségi teszteket a mozgásprogramok kezdetekor (bemeneti állapot), majd a 10 hetes mozgásprogram végeztével (kimeneti állapot) teljesítették.

\section{ADATELEMZÉS}

Az egészségmegőrző mozgásprogramokon résztvevők Hungarofit felmérésen kapott eredményeinek statisztikai elemzése során átlagot, szórást számoltunk, megállapítottuk a minimum és maximum értékeket az egyes csoportoknál. Az alapstatisztikai számítások (átlag, szórás, t-próba) elvégzése után, az adatok komplexebb elemzésére is sor került. Az egy populációból vett alminták szóráshomogentásának megállapítása érdekében Levene próbát futattunk. Az ANOVA teszt elvégzése után Tukey post hoc tesztet is végeztünk, hogy az összes csoport és változók közti „valós” különbségeket is felfedhessük. A szélesebb körű elemzés eredményeit egy későbbi dolgozatban mutatjuk majd be. Jelen dolgozatban hatvan hallgató, a 2018/19-es tanév második félévében felmért teljes adatsorát vizsgáltuk meg.

\section{EREDMÉNYEK}

$\mathrm{Az}$ aerob állóképességet felmérő 20 méteres ingafutás (Beep teszt) tekintetében a legnagyobb mértékű (44 százalékos) szignifikáns fejlődést $(\mathrm{p}<0,05)$ a wellness-általános kondicionálás foglalkozásokon résztvettek esetében regisztráltunk. A spinning mozgásforma szintén jelentősen javította (33 százalékkal) az aerob mutatókat a bemeneti teszthez képest, ebben az esetben az alacsony elemszámból ( $n=5)$ fakadóan nem tudtunk alapstatisztikát számolni. A sorrendben harmadik leghatékonyabb mozgásforma az általunk vizsgált mintánál az alakformálás lett. A résztvevők átlagosan 22 százalékkal javították meg év eleji teljesítményüket, a változás szignifikáns volt $(\mathrm{p}<0,05)$. Végül a pilates csoport tagjai is javultak, igaz a fejlődés mértéke elmaradt a többi csoporthoz 
Vol 3, No 2 (2020): Stadium-Hungarian Journal of Sport Sciences

https://doi.org/10.36439/SHJS/2020/2/8599

képest, 16 százalék volt, a különbség ebben az esetben is szignifikáns volt $(\mathrm{p}<0,05)(1$. ábra).

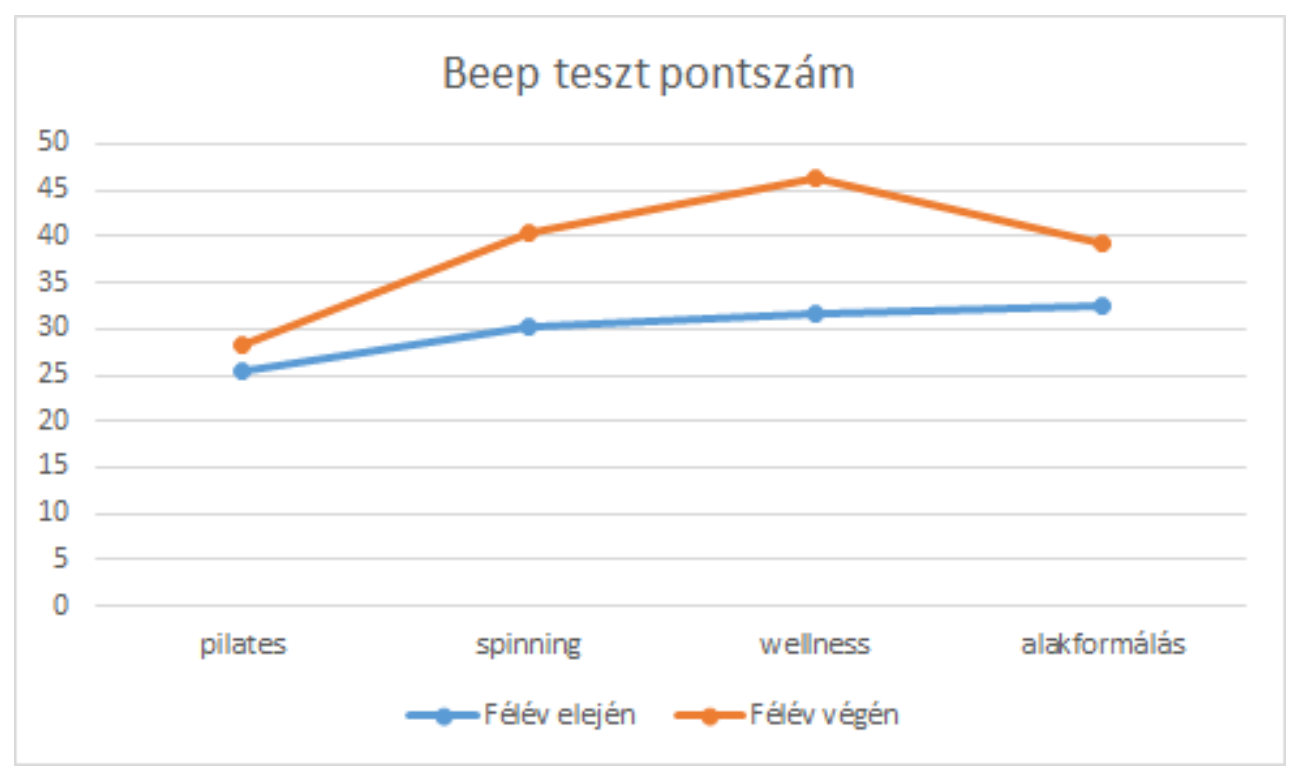

1. ábra: a négy csoport Beep teszt átlagértékei

A felső végtag erő-állóképességét mérő karhajlítás-nyújtás próbában szintén a wellnessáltalános kondicionálás csoportban résztvevők teljesítettek a legjobban. Átlagosan 57 százalékos szignifikáns $(\mathrm{p}<0,05)$ javulást tapasztaltunk a bemeneti és a kimeneti felmérések viszonylatában. A pilates és az alakformálás mozgásformák egyaránt hatékonynak bizonyultak. E két csoportnál 46 illetve 43 százalékos javulást mérhettünk, mely mindkét esetben szignifikánsnak bizonyult $(\mathrm{p}<0,05)$. A spinning edzéseken résztvevők fejlődésének mértéke lett a legszerényebb, e csoport tagjai mindössze 11 százalékkal nyújtottak jobb teljesítményt az első felméréshez képest (2. ábra). 
Vol 3, No 2 (2020): Stadium-Hungarian Journal of Sport Sciences https://doi.org/10.36439/SHJS/2020/2/8599

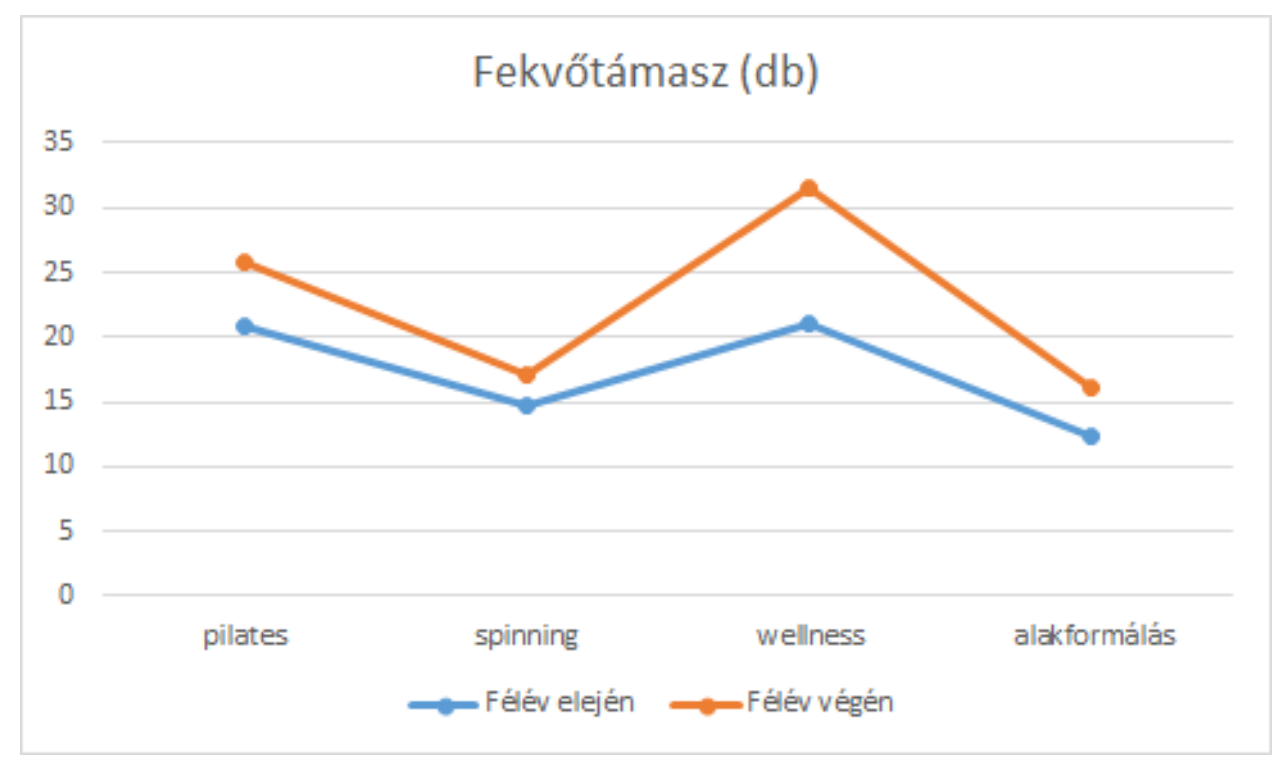

2. ábra: a négy csoport fekvőtámasz átlagértékei

A hasizom erő-állóképességét felmérő hasizom teszt esetében is a wellness-általános kondicionálás órán résztvevő hallgatók fejlődése volt a legnagyobb mértékű. A kimeneti teszteken átlagban 73 százalékos, szignifikáns $(\mathrm{p}<0,05)$ javulást mérhettünk. A spinning mozgásforma is eredményesnek bizonyult, hiszen az eredmények 31 százalékkal javultak. Az alakformálás órán résztvevőknél is hasonló szintű 28 százalékos javulást mutattunk ki. A pilates edzésforma esetén mért eredményjavulás 13 százalékos mértékű volt. A változások utóbbi két esetben szignifikánsak voltak $(\mathrm{p}<0,05)$ (3.ábra).

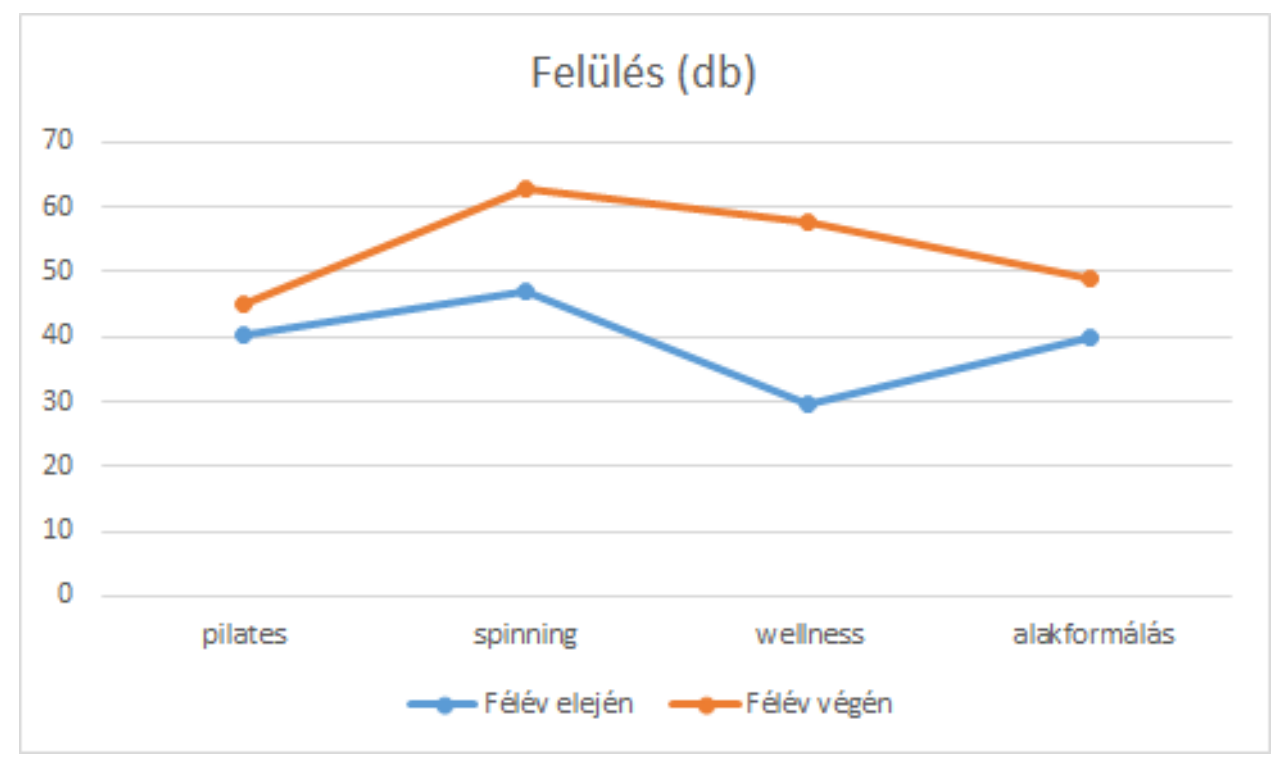

3. ábra: a négy csoport felülés átlagértékei 


\section{MEGBESZÉLÉS}

Fiatal, korábban inaktív felnőttek a Debreceni Egyetem hallgatói a 10 hétig tartó, heti egyszeri, 90 percig tartó fizikai aktivitás hatására mindhárom motoros próba (Beep teszt, fekvőtámasz, felülés) tekintetében javulni tudtak (1. táblázat). A változás több esetben statisztikailag is szignifikáns volt $(\mathrm{p}<0,05)$. Első alapfeltevésünk így beigazolódott.

1. táblázat: változás mértéke az egyes mozgásprogramok esetén

\begin{tabular}{|c|c|c|c|}
\hline 2018/19 II. FÉLÉV & \multicolumn{3}{|c|}{ VÁLTOZÁS (SZázalékban) } \\
\hline & BEEP teszt & FELÜLÉS & FEKVÓTÁMASZ \\
\hline PILATES & 16 & 13 & 46 \\
\hline SPINNING & 33 & 31 & 11 \\
\hline WELLNESS & 44 & 73 & 57 \\
\hline ALAKFORMÁLÁS & 22 & 28 & 43 \\
\hline
\end{tabular}

Második alapfeltevésünk is beigazolódott, miszerint a négy különböző sporttevékenység (alakformálás, wellness-általános kondicionálás, spinning, pilates) más-más mértékben hat a vizsgált motoros képességek kimeneti színvonalára.

A wellness-általános kondicionálás mozgásforma erő-állóképességi gyakorlatokon alapult, az erősítő jellegű és az állóképesség-fejlesztő gyakorlatok aránya közel egyező volt. Mindhárom motoros próba tekintetében ez a mozgásforma bizonyult a leghatékonyabbnak, azaz mind az ingafutásban, mind a fekvőtámasz és felülés tesztekben ez a csoport teljesített a legjobban. A döntően aerob igénybevétellel járó mozgásformák, mint az alakformálás és spinning szintén jelentősen javították az aerob teljesítőképességet. Elvárható volt, hogy a két edzésforma összehasonlításában a spinning esetében regisztráljunk jelentősebb mértékű (33 százalékos) fejlődést, hiszen a spinning intenzív, állóképességi mozgásforma.

A fekvőtámasz tesztek esetén a pilates csoport tagjai jelentősen javítani tudtak eredményeiken, hiszen a pilates kisebb mozgás-kiterjedésű és statikusabb gyakorlatai kimondottan elősegítik a felső végtagi erőszint fejlődését. A spinning dominánsan alsó végtagi terheléssel jár, így a karhajlítás-nyújtás próbában mért szerényebb javulás teljesen evidensnek tűnik.

A felülés próbában a spinning és az alakformálás csoport tagjai közel hasonló mértékben (30 százalék körül) tudtak fejlődni. A spinning esetében ez az eredmény meglepő, bár a különböző testtartásban végzett spinning (kerékpáros) mozgás a törzsizmokat is jelentősen igénybe veheti. A pilates csoport tagjai javulás mértékét tekintve jelentősen elmaradtak a többiektől.

A testnevelés órákon alkalmazott terhelés mind a négy edzésforma esetén közepesen erős (70 százalék körüli) intenzitású volt, bár ezt objektív adatokkal (pulzusszám) nem tudtuk alátámasztani, hiszen az egyes foglalkozásokon nem volt módunkban pulzuskontrollt (Polar óra, okos óra) alkalmazni. 
A jövőben az adatok jobb összehasonlíthatósága érdekében azonos módszerrel még nagyobb tömegek felmérésére lenne szükség. A különböző földrajzi régiókból érkező adatok alapján általános következtetéseket tudnánk levonni, amely elősegítené a fiatal felnőttek egészségi állapotának, motoros képességei színvonalának felmérését és javítását.

A publikáció elkészítését a 2014-2020 - GINOP 2.3.2.-15-2016-00062 projekt támogatta. A projekt az Európai Unió támogatásával, az Európai Szociális Alap társfinanszírozásával valósult meg.

\section{IRODALOMJEGYZÉK}

Antal M., Nagy K., Bíró L., Greiner E., Regöly-Mérei A., Domonkos A., Balajti A., Szabó, C., \& Mozsárí E. (2003). Cross-sectional survey on the nutritional and life-style habits of secondary school students in Hungary. Hung. Med. J., 144, 1631-1636.

Ács P., Hécz R., Paár D., \& Stocker M. (2011). A fittség (m)értéke - a fizikai inaktivitás nemzetgazdasági terhei Magyarországon, Közgazdasági Szemle, 689-708.

Barabas A., Fábian, Gy., \& Ozsvath, K. (1992). Motor fitness investigation in Hungary by Eurofit tests. International Council for Physical Fitness Research (ICPER). Symposium 92, Leuven 10-13.

Bartha É., Perényi Sz. (2015). A fitneszipar és trendjei. In Sz. Perényi (szerk.) Szabadidősport társadalmi és gazdasági kérdései, 72-94. Tananyag az „ABS” Képzés- és rendszerfejlesztés a sportos társadalomért Észak - Kelet Magyarországon (A és B komponensek a felsőoktatási Sport fejlesztéséért) TÁMOP-4.1.2. E-13/1/KONV-20130010 számú projekt támogatásával.

Bucsy G., Katona, Gy. (2002). Motor level, physical fitness research of female college students. Hung.Rev. Sport Sci., 1, 8-11.

Caspersen C. J., Pereira M. A., \& Curran K. M. (2000). Changes in physical activity patterns in the United States, by sex and cross-sectional age. Med Sci Sports Exerc., 32, (9) 16011609.

Flegal K. M., Kit, B. K., Orpana, H., \& Graubard, B. I. (2013). Association of All-Cause Mortality With Overweight and Obesity Using Standard Body Mass Index Categories. JAMA, 309, (1), 71-82.

Frenkl R. (1997). Testösszetétel, fittségi állapot (Body composition, physical fitness). In: Som, F. (ed.) Felsőoktatás, Értelmiség, Egészség, Budapest, 17-50. 
Garber C. E., Blissmer, B., Deschenes M. R. et al. (2011). American College of Sports Medicine position stand. Quantity and quality of exercise for developing and maintaining cardiorespiratory, musculoskeletal, and neuromotor fitness in apparently healthy adults: guidance for prescribing exercise. Med Sci Sports Exerc., 43, (7), 1334-59.

Hamar P., Peters D. M., Van Berlo K., \& Hardman K. (2006). Physical education and sport in Hungarian schools after the political transition of the 1990s. Kinesiology, 38, 86-93.

Kaj M., Tékus É., Juhász I., Stomp K., \& Wilhelm M. (2015). Changes in physical fitness of Hungarian college students in the last fifteen years, Acta Biologica Hungarica, 66, (3), 270281.

Kaj M. (2017). Maximális oxigénfelvevő-képesség becslési módszereinek keresztvaliditási vizsgálata magyar iskoláskorú gyerekeken, Doktori (PhD) értekezés, Pécsi Tudományegyetem, Egészségtudományi Doktori Iskola

Konczos Cs., Bognár J., Szakály Zs., Barthalos I., Simon I., \& Oláh Zs. (2012). Health awareness,motor performance and physical activity of female university students. Biomed. Hum. Kinetics, 4, 12-17.

Kopp M., Skrabski Á. (2009). Európai lakossági egészségfelmérés, Központi Statisztikai Hivatal.

Kovács E., Keresztesi K., Gombocz J., András-Teleki J., \& Kovács I. (2002). The role of physical education in higher education and possibilities for its development. Kalokagathia, 40, 114-121.

Moore S. C., Patel A. V., \& Matthews C. E. et al., (2012). Leisure Time Physical Activity of Moderate to Vigorous Intensity and Mortality: A Large Pooled Cohort Analysis. Plos Medicine, 9, (11), 1-14.

Perényi Sz., Petridis L. (2015). Bevezetés a sporttudományokba. A tananyag elkészítését a "3. misszió" Sport és tudomány a társadalomért Kelet-Magyarországon TÁMOP-4.1.2.E15/1/Konv-2015-0001 számú projekt támogatta. Campus Kiadó, Debrecen.

Pribis P., Burtnack C. A., \& McKenzie S. O. et al., (2010). Trends in Body Fat, Body Mass Index and Physical Fitness Among Male and Female College Students. Nutrients, 2, 1075 1085.

Steptoe A, Wardle J, Cui, W, Bellisle F, Zotti A.M, Baranyai, R., \& Sanderman, R. (2002). Trends in Smoking, Diet, Physical Exercise, and Attitudes toward Health in European University Students from 13 Countries, 1990-2000, Preventive Medicine, 35, (2), 97-104.

Telama R., Yang X. (2000). Decline of physical activity from youth to young adulthood in Finland. Med Sci Sports Exerc., 2, (9), 1617-1622. 
Vol 3, No 2 (2020): Stadium-Hungarian Journal of Sport Sciences

https://doi.org/10.36439/SHJS/2020/2/8599

Warburton D. E. R., Nicol C. W., \& Bredin S. S. D. (2006). Prescribing exercise as preventive therapy. CMAJ, 174, (7), 961-974.

Wen C. P., Wai J. P. M., \& Tsai M. K. et al., (2011). Minimum amount of physical activity for reduced mortality and extended life expectancy: a prospective cohort study. Lancet, 378, (9798), 1244-1253.

World Health Organization (2018). Physical Activity Factsheet, for the 28 European Union member states of the WHO European region. 